\title{
Henryk DUDA
}

Katolicki Uniwersytet Lubelski Jana Pawła II

henryk.duda@kul.pl

http://orcid.org/0000-0002-5514-7515

\section{KWOLEK CZY CHWAEEK? \\ O NAZWISKU RODOWYM SEYNNEJ CHEMICZKI}

Stephanie Louise Kwolek to amerykańska chemiczka polskiego pochodzenia ${ }^{1}$. Stała na czele zespołu, który w 1965 roku wynalazł polimer, z którego wytwarzany jest kevlar. Z włókien kevlarowych produkuje się m.in. kamizelki kuloodporne, kaski, hełmy etc. Urodziła się 31 lipca 1923 w New Kensington w Pensylwanii. Zmarła 18 czerwca 2014 r. w Wilmington. Jej rodzice - John Kwolek i Nellie (Aniela ${ }^{2}$ ) Kwolek z domu Zajdel, wyemigrowali z Polski we wczesnej młodości. Stephanie uczęszczała do prowadzonej przez zakonnice katolickiej szkoły w New Kensington. W 1946 ukończyła chemię w Margaret Morrison Carnegie College w Carnegie Mellon University w Pittsburghu (Pensylwania, USA). Następnie chciała studiować medycynę, lecz z powodu problemów materialnych podjęła pracę jako chemik w firmie DuPont z myślą o zebraniu funduszy na studia medyczne. Studiów tych nigdy nie podjęła. Przeszła do historii nauki jako wybitny wynalazca (dzisiejszy zwyczaj językowy

1 Informacje bibliograficzne pochodzą z powszechnie dostępnych źródeł internetowych, jak np. Wikipedia, oraz z różnych publikacji o charakterze biograficznym, np. M. Bailey, American Women in Science: 1950 to the Present: a Biographical Dictionary, Santa Barbara, CA 1998, s. 224-225; R. Swaby, Upór i przekora: 52 Kobiety, które odmieniły naukę i świat, Warszawa 2017, czy specjalistycznych prac z zakresu nauk ścisłych, np. W. Brostow, H.E.H. Lobland, Materials: Introduction and Applications, Hoboken, New Jersey 2016, s. 178, i nekrologów, np. S. Ainsworths, Stephanie Kwolek Dies at 90, "Chemical \& Engineering News" t. 92,2014 , nr 26 , s. 8 .

2 Imię Aniela widnieje na grobie rodzinnym Kwolków w Lower Burell obok New Kensington w stanie Pensylwania (USA). Zdjęcie nagrobka zob. W. Iwańczak, Kobieta, która zatrzymała pociski. Nowe fakty, „Niedziela” 2016, nr 44, s. 23. 
każe pisać wybitna wynalazczyni), posiadaczka 28 patentów z zakresu chemii. Kierowała laboratorium w firmie DuPoint aż do przejścia na emeryturę w 1986 r. Za swoje osiągnięcia otrzymała wiele nagród i wyróżnień, m.in. znalazła się w National Inventors Hall of Fame (1994), otrzymała National Medal of Technology (1999) oraz Perkin Medal. Jak podkreślają amerykańskie źródła, „all rare honors for women”3. Podaję tu jedynie podstawowe informacje, gdyż biografia Stephanie Kwolek nie jest przedmiotem tego artykułu. Interesuje mnie bowiem tylko jeden szczegół w jej życiorysie - nazwisko rodowe, tj. nazwisko, „które uzyskuje osoba w momencie urodzenia, wpisane do aktu urodzenia" (Kasprzyk 2006: 51) oraz społeczny kontekst jego funkcjonowania.

Punktem wyjścia naszych rozważań będą istniejące już publikacje, przeważnie o charakterze popularnym (popularnonaukowym). Kwestia ta była już bowiem przedmiotem uwagi dziennikarzy, m.in. dwukrotnie o Stefanii (za oceanem nosiła imię w wersji angielskiej: Stephanie) Kwolek pisał w tygodniku "Niedziela” Witold Iwańczak. Pierwszy z jego tekstów ma charakter informacyjny (Iwańczak 2016: 44-45). Natomiast pretekstem do napisania drugiego artykułu był list p. Piotra Kwolka z Komborni (Podkarpacie) do P.T. Redakcji tygodnika katolickiego „Niedziela”, jak się okazuje bliskiego krewnego Stefanii, który zwrócił uwagę m.in. na fakt,

że nazwisko Kwolek wszędzie ma zachowaną swoją pisownię, a sprawdzał to $\mathrm{w}$ posiadanych $\mathrm{w}$ rodzinie starych dokumentach oraz $\mathrm{w}$ księgach parafialnych. Nikt nie wie, skąd $w$ amerykańskich publikacjach pojawiły się informacje, jakoby Kwolek pisało się wcześniej jako Chwałek (Iwańczak 2016: 22).

„Z Komborni w świat” wyruszył nie tylko Jan Kwolek, ojciec Stefanii. Stanisław Pigoń (1885-1968), wybitny historyk literatury, rektor Uniwersytetu Stefana Batorego w Wilnie (1926-1928), po II wojnie światowej profesor Uniwersytetu Jagiellońskiego w Krakowie, urodzony w tej samej wsi, przedstawiając jej dzieje, tak pisze o jej mieszkańcach:

Ludność to zasiedziała; nie zdaje się, żeby w składzie mieszkańców przez przeciąg wieków zaszła jakaś gwałtowna i gruntowna zmiana. Wśród zapisek odnoszących się do XV i XVI wieku znajdujemy mnóstwo nazwisk znanych tu do dzisiaj: Michael Praysner de Calbornia (1461), Jakiel

3 Zob. https://www.acs.org/content/acs/en/education/whatischemistry/women-scien tists/stephanie-kwolek.html (dostęp: 15.02.2019). 
Koznar (1463), Długosz (1486), Wojnar (1512), Kielar, Cynkar, Kasprzyk, Świątek, Gierlach, Surmacz, Szyndlar, Kwolek [podkr. moje - H.D.], Pelc, Kłapkowski, Miśkowiec, Hawrot i in., wszystko to rodziny, które trwają po dziś dzień i gospodarują w Komborni czy Woli Komborskiej. [...] Widzimy, że spora część obecnych gospodarzy siedzi tu z dziada pradziada, od pięciuset, a może więcej lat (Pigoń 1983: 78).

Wydaje się, że - czym tu nie będziemy się zajmować - rodzina Pigoniów pozostawała w jakimś kontakcie z rodziną Kwolków, z których wywodzi się Stefania. Matką chrzestną przyszłego badacza literatury była żona Jana Kwolka, o którym Pigoń pisze m.in., że „sąsiad niedaleki, mój (przez swą żonę) «krzesnojciec», Jan Kwolek, zwany Zawęwozianem" (Pigoń 1983: 119). „Krzesnojciec” Pigonia był zapewne o pokolenie starszy od ojca Stefanii, także Jana, w źródłach amerykańskich nazywanego też Johnem.

Rówieśnikiem Pigonia był także ks. dr Jan Kwolek (1885-1958), urodzony w Kraczkowej, kapłan diecezji przemyskiej. Jan Bielatowicz, emigracyjny prozaik, poeta i krytyk literacki rodem z Niska, tak go wspomina: „przyjaciel mego ojca, pono illo tempore sława gimnazjum rzeszowskiego, potem teolog i esteta, biskup sufragan przemyski" (Bielatowicz 1986: 8). Słynnych Kwolków można wymienić więcej. Tak jak „nie jednemu psu Burek", nie wszyscy (Janowie) Kwolkowie muszą pochodzić z tej samej rodziny. Tych tutaj przypominam, by zwrócić uwagę na ich pochodzenie z Podkarpacia, do czego jeszcze wrócimy, oraz na fakt, że nazwisko Kwolek, tak w przeszłości, jak i obecnie jest dobrze udokumentowane.

Nazwisku rodowemu słynnej chemiczki warto poświęcić nieco uwagi, gdyż problem może zainteresować nie tylko tych, którzy chcieliby wiedzieć, jak naprawdę nazywała się (albo inaczej, jak powinna się nazywać, czy też jak mogłaby się nazywać) amerykańska wynalazczyni, lecz także wszystkich, którzy noszą nazwiska takie jak:

1. Chwałek (po raz pierwszy poświadczone w 1390 r.), Chwałk (północnopolski odpowiednik nazwiska Chwałek (Rymut 1992: 139)), Chwalek, Chwalik, Chwalczyk, Chwalczuk, Chwalkiewicz i podobne (tamże, 138-139).

2. Kwałek, Kwal, Kwalc, Kwalek, i niektóre inne zaczynające się Kwałi/lub Kwal- (Rymut 1993: 483); Kwolek, Kwolik, Kwolewski, Kwolkiewicz i niektóre inne zaczynające się od Kwot-/Kwol- (tamże, 494), także Kwolke i Kwoll (w dwu ostatnich nazwiskach widać kontakt z językiem niemieckim). 
3. To samo pochodzenie mają także liczne nazwiska $\mathrm{z}$ rdzeniem Fat-/Fal-, np. Fałek, Fałęta, Fałowski (Rymut 1993: 56-57), Falek, Falenski, Falenta etc. (Rymut 1993: 52), w których poświadczone jest małopolsko-mazowieckie przejście grupy spółgłosek chw- w f- (Rymut 1991: 99).

4. Mniej oczywiste są w tym kontekście nazwiska z nagłosowym ch-, takie jak np. stp. Chalęta, Chalimir, Chalisław, tj. z uproszczeniem grupy chw-do ch- (Rymut 2003: 294).

5. Dla porządku jedynie dodajmy jeszcze nazwy $\mathrm{z}$ nagłosowym $w$-<chw-. Nie podejmując próby szukania ich we współczesnych nazwiskach polskich, gdyż zbyt daleko wykracza to poza cel tego artykułu, za Kazimierzem Rymutem wspomnijmy jedynie, że Słownik staropolskich nazw osobowych (1956-1987) zna Waliboga (ze Szczytnik). W dokumentach średniowiecznych nazwę tę zapisano dwukrotnie, raz jako Chwalibogius Sczitniczski (1413 r.) i Waliboyus de Sczitniky (1420 r.) (Rymut 1991: 295).

Choć z punktu widzenia współczesnego odbiorcy mamy tu co najmniej pięć gniazd nazewniczych (,zespołów nazw motywowanych przez jeden i ten sam rdzeń" (Raszewska-Klimas 2002: 15)), to z punktu widzenia genezy języka polskiego wszystkie one tworzą jedno gniazdo nazewnicze - we wszystkich bowiem można odnaleźć psł. rdzeń *xvali- obecny m.in. w polskim czasowniku chwalić.

Do uwagi p. Piotra Kwolka dodajmy jeszcze, że nie tylko w publikacjach amerykańskich można znaleźć informację, że nazwisko Kwolek to pierwotne $\mathrm{i} /$ lub zanglicyzowane, zamerykanizowane polskie nazwisko Chwałek (Chwalek). Jak podaje jedna z czeskich stron internetowych:

Stephanie Kwoleková má v rodném listu jako místo narození uveden americký New Kensington, nicméně prúijmení př́liš americky nezní. Zapátráme-li po jejím původu, dostaneme se do Polska a zjistíme, že Kwolek je „amerikanizované" př́ijmení rodičů - Chwałek 4 .

[Stefania Kwolek ma w akcie urodzenia wpisane jako miejsce urodzenia amerykański New Kensington, jednak jej nazwisko nie brzmi zbyt amerykańsko. Jeśli zaczniemy szukać jego pochodzenia, dotrzemy do Polski i dowiemy się, że Kwolek to „zamerykanizowane" nazwisko jej rodziców Chwałek. - przeł. H.D.]

4 Zob. https://zoommagazin.iprima.cz/valky/kdo-ma-na-svedomi-vynalez-neprustrel ne-vesty-svete-div-se-zena (dostęp: 13.02.2019). Zob. też: „Ihre Eltern John und Nellie Kwolek waren aus Polen nach Amerika eingewandert, sie hiessen ursprünglich Chwalek" [Jej rodzice, John i Nellie Kwolek, wyemigrowali z Polski do Ameryki, ich pierwotne nazwisko brzmiało Chwalek - przekł. H.D.] D. Meier, Ein goldener Faden, der Leben rettet, „Neue Zurcher Zeitung”, 29 VI 2014 r. 
Zacznijmy od tego, że jeśli p. Piotr Kwolek sprawdził w dokumentach, jaką postać miało nazwisko jego przodków, to - w pewnym sensie - nie mamy o czym dyskutować. Ojciec Stephanie miał na imię Jan i wyemigrował z Podkarpacia z nazwiskiem Kwolek. Ta opinia zgadza się także z przywołanymi wcześniej ustaleniami Stanisława Pigonia. Nie może to więc być, jak podaje m.in. polska Wikipedia, „zniekształcona forma «Chwałek»" albo - jak pisze w „Gazecie Krakowskiej” (20 IV 2016) prof. Ryszard Tadeusiewicz:

Jest także rzeczą dowiedzioną, że nazwisko Kwolek jest zamerykanizowaną wersją swojskiego nazwiska Chwałek, a rodzice Pani Stefanii (która sama urodziła się w Pitsburghu w USA) z całą pewnością wywodzili się z Polski ${ }^{5}$.

Tak jak w przypadku artykułów Wiktora Iwańczaka w tygodniku „Niedziela", tak i po felietonie Tadeusiewicza w "Gazecie Krakowskiej” odezwała się wyczulona na punkcie swojego nazwiska rodzina. W internetowym komentarzu głos zabrała Jolanta Gibała z domu Kwolek:

Szanowny Panie Stefania KWOLEK jest moją ciotką. Jej ojciec JAN był bratem mojego dziadka STANISŁAWA KWOLEK a nie CHWAŁEK. Pochodzą z KOMBORNI na PODKARPACIU. Nie wiem z kąt Pan posiada takie błędne informacje. KOMBORNIA to nasza rodzinna miejscowość tu są nasze korzenie. Stefania KWOLEK miała jeszcze brata STANISŁAWA KWOLEK mieszkającego w USA ${ }^{6}$.

Nie ma racji - dodajmy przy okazji - także prof. Andrzej Nowak, krakowski historyk, który w ankiecie dwumiesięcznika „Arkana"7 o Stefanii Kwolek pisze "córka Jana Chwałka” (Nowak 2013: 32).

$\mathrm{Z}$ całą pewnością nie przekształcili nazwiska Chwałek w nazwisko Kwolek amerykańscy urzędnicy imigracyjni, choć takie zniekształcenia były w przeszłości na porządku dziennym (Bystroń 1936: 233-234), m.in. w dokumentach osadników „nazwisko jest pisane według indywidualnej interpretacji urzędników" (Jost 1983: 45). Nie jest wreszcie nazwisko Kwolek tworem sztucznym, powstałym w wyniku ucieczki Stefanii

5 Wcześniej R. Tadeusiewicz, O życiu i nauce (zbiór felietonów), SKAMER ACM 2012, s. 77; tenże, Kamizelki $i$ hetmy kuloodporne z kevlaru, czyli co zawdzięczaja żotnierze Stefanii Kwolek vel Chwałek, „Gazeta Krakowska”, 2016.

6 Zob. https://gazetakrakowska.pl/kamizelki-i-helmy-kuloodporne-z-kevlaru-czyli-cozawdzieczaja-zolnierze-stefanii-kwolek-vel-chwalek/ar/9897449 (dostęp: 15.02.2019). Pisownia i interpunkcja autorki komentarza.

7 Ankieta "Arcanów". Polska i jej przeszłość w świadomości i pamięci historycznej, "Arcana” 2013, nr 112-113, s. 13-32. 
bądź jej rodziców od polskiej tożsamości. Ucieczkę od nazwisk polskich można zauważyć $w$ różnych środowiskach emigracyjnych, a jej źródłem mogą być czynniki praktyczne (ucieczka od skomplikowanej z punktu widzenia obcego środowiska językowego ortografii i/lub wymowy polskiej) bądź społeczne (ucieczka od negatywnego stereotypu Polaka w danym środowisku, prejustice, social embarrassement) (Kaleta 1998: 168-184; tejże 1997: 11-115). Nie znaczy to jednak, że nie potrafimy wyjaśnić, skąd się wzięło nazwisko Chwałek i dlaczego niektórzy, wbrew dokumentom upatrują w formie Kwolek pierwotnego Chwatek.

Zarówno wyliczone wyżej przykładowo nazwiska typu Kwolek, jak i miana typu Chwałek mają to samo pochodzenie. Ich źródłem są albo staropolskie imiona dwuczłonowe typu Chwalimir, Chwalisław, Boguchwał albo wyraz pospolity - czasownik chwalić (Rymut 1991: 99). Ścisłej granicy tu być nie może, gdyż pierwszy człon wspomnianych imion staropolskich także zawiera rdzeń tego czasownika. Jeśli przyjąć, że nazwisko Chwałek pochodzi od staropolskich imion złożonych, to pozostawałoby w takiej samej relacji do Chwalimira bądź Chwalisława jak Sławek do Sławomira i Władek do Władysława ${ }^{8}$. Co do genezy byłoby zdrobnieniem pierwszego stopnia. Możliwa jest także pośrednia relacja między nazwiskiem Chwałek a wskazanymi wyżej imionami złożonymi - Chwałek mogło zostać utworzone za pomocą sufiksu -ek od staropolskiego imienia Chwat, które z kolei byłoby zdrobnieniem lub derywatem wstecznym o charakterze patronimicznym od Chwalimira bądź Chwalisława.

Jeśli przyjąć, że wywodzi się od czasownika chwalić, to wtedy miałoby charakter przezwiskowy, nazwa charakteryzowałaby odległych przodków w linii męskiej jego nosiciela - Chwałek to 'ten, który lubi się chwalić' (Łobodzińska, Tomczak 1988; Cieślikowa 1998: 119-134). Ponieważ rzeczownik pospolity chwałek 'samochwalca, samochwała' poświadczony jest w materiale językowym słabo, bo tylko raz w Słowniku gwar polskich Jana Karłowicza (1900-1911) ${ }^{9}$, raz w Oświęcimskiem w pracy Wandy

\footnotetext{
8 Z dzisiejszej perspektywy formy Sławek i Władek to imiona zdrobniałe. W perspektywie historycznej jednak są to nazwy osobowe, antroponimy, które niejednokrotnie stawały się później nazwiskami, np. moja mocno już przestarzała (koniec XX w.) książka telefoniczna województwa lubelskiego notuje 23 Sławków oraz 1 osobę o nazwisku Władek. Nazwom osobowym tego właśnie typu poświęcona jest monografia Marii Malec Staropolskie skrócone nazwy osobowe od imion dwuczłonowych, Wrocław 1982. O nazwie osobowej (nazwisku) Chwałek i Kwalek zob. tamże, s. 68.

9 Słownik gwar polskich PAN (red. J. Reichan, t. 4, z. 1(10), Kraków 1992, s. 163) pod hasłem chwałek odnotował postać gwarową kválek z Tarnobrzeskiego.
} 
MAPA 1. Schematyczny zasięg zmiany grupy chw- w $k w-\mathrm{w}$ dialektach polskich

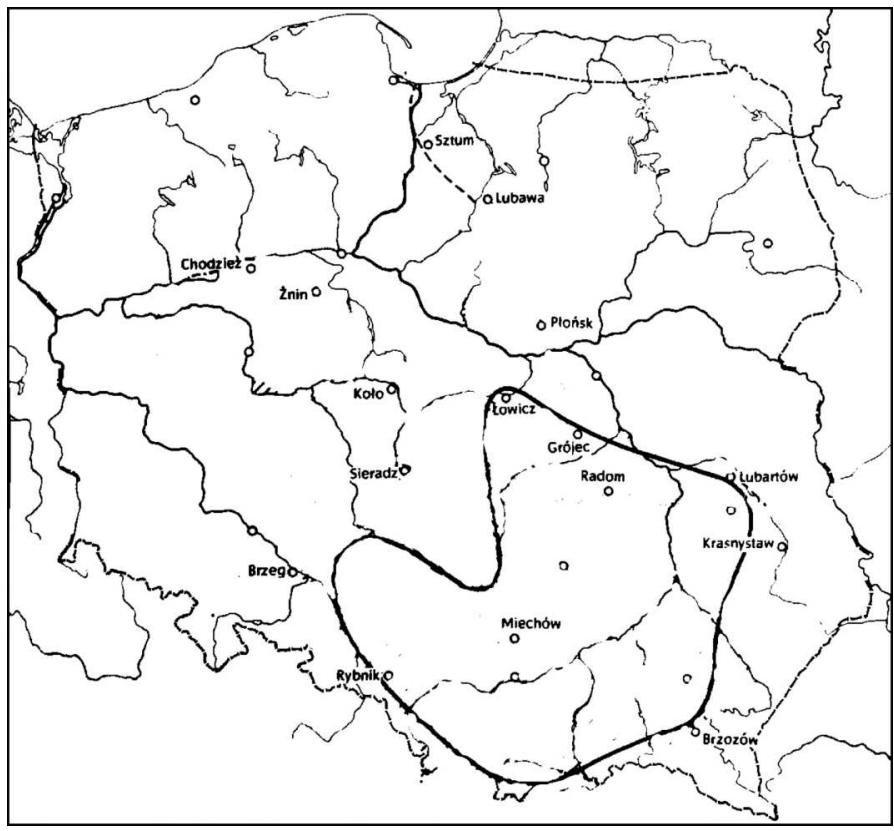

Pomianowskiej (1963: 13), to wywód nazwisk(a) Chwałek/Kwałek/Kwołek/ Fałek i in. od staropolskich imion złożonych wydaje się zasadniejszy.

Nazwiska z początkowym chwa- mają ogólnopolską, standardową, literacką postać fonetyczną. Te natomiast, które zaczynają się od kwa-/kwo-, mają postać gwarową. Widzimy tu najpierw $k w$ - (w wymowie większości Polaków $k f-$ ) w miejsce literackiego chw- (w wymowie chf-). To zjawisko obejmuje gwary małopolskie i śląskie. Schematyczny zasięg pokazuje mapa nr $1 .{ }^{10} \mathrm{~W}$ nazwiskach $\mathrm{z}$ rdzeniem Kwał-/Kwal- utrwaliła się ta właśnie cecha gwarowa. Natomiast w nazwisku Kwolek i w innych z Kwot-/Kwol- widzimy jeszcze jedną właściwość gwarową. Literackiej samogłosce $a$ odpowiada w nazwisku Kwolek gwarowe $o$. Językoznawcy mówią w tym wypadku o tzw. a pochylonym. Może to być w gwarach polskich głoska równa samogłosce o (znaczna część Małopolski, Śląska, Wielkopolski i Mazowsza) lub samogłoska pośrednia między samogłoską $a$ oraz samogłoską $o$, zapisywana fonetycznie w różny sposób

10 Mapa stanowi ekstrakt z mapy nr 15 opracowanej przez Karola Dejnę w jego Dialektach polskich (Wrocław 1993). 
np. á lub å (południowo-wschodnia Małopolska). Kto oglądał uważnie Janosika - ze względu na odbiorcę tego tekstu, niekoniecznie lingwistę, specjalistę od fonetyki gwarowej, pozwalam sobie tu w taki niekonwencjonalny sposób zilustrować, o jaką wymowę chodzi (Kresa 2014: 22-41) - ten zapewne zapamiętał, jak często Kwicoł (literackie Kwiczał) używał wyrazu prowda zamiast standardowego prawda. A pochylone występuje na nieco szerszym obszarze Polski niż przejście chw- w kw-. „Występowanie litery $o \mathrm{w}$ miejsce ogólnopolskiego $a$ i gwarowego $a$ pochylonego, np. Bednorz (1556) / ogólnego Bednarz (13 tys.), Loska (843), Morcinek (912), Szyndzielorz (119) spotykane jest w wielu gwarach, a szczególnie na Śląsku." (Malec 1996: 59). Schematyczny zasięg pokazuje mapa nr $2^{11}$. Jest ono wyraźnie rozpoznawane jako cecha gwarowa.

MAPA 2. A pochylone w gwarach polskich

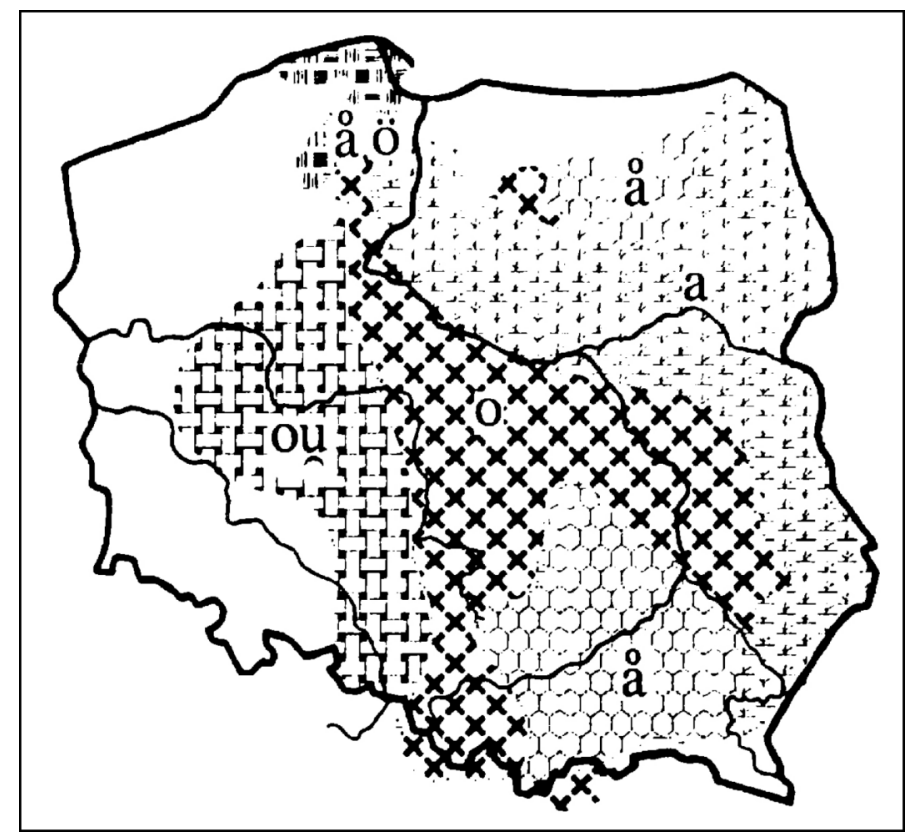

Osobną kwestią jest głoska $l \mathrm{w}$ nazwisku Kwolek wobec głoski $\ell$ w nazwisku Chwałek. Historyczne pierwszeństwo ma tu $\ell$ (przed polskim -ek $\mathrm{z}$ prasłowiańskiego ${ }^{*}$-ъkr powinna być spółgłoska twarda $\mathrm{z}$ wyjątkiem $j$

11 Źródło: M. Kucała, Twoja mowa cię zdradza, Kraków 2002, s. 9. Więcej szczegółów zob. mapa nr 33, [w:] K. Dejna, Dialekty polskie, Wrocław 1993. 
i spółgłosek $c z \dot{z} s z$ z prasłowiańskich $k g$ (Łoś 1925: 73-74). Nazwiska z nagłosowym Chwal- i Kwal-/Kwol- mogły powstać przez wtórne skojarzenie $\mathrm{z}$ czasownikiem chwalić ( $\mathrm{w}$ lingwistyce ten proces nazywa się adideacją). Inne możliwe wyjaśnienie genezy badanych nazwisk $\mathrm{z}$ tematycznym -l- to przyjęcie, że Chwalek (gwarowe Kwalek, Kwolek) wywodzą się od staropolskiej nazwy osobowej Chwal (z wcześniejszego Chwali), która genetycznie jest formą rozkaźnika od czasownika chwalić (Rymut 1998: 154: „Liczniej występują w funkcji nazw osobowych czasowniki w formie rozkaźnika, np. Czekaj, Witaj").

Wszystkie opisane tu w pewnym uproszczeniu procesy zaszły w odległej przeszłości, na długo przed drugą połową XIX w., kiedy rodzice Stefanii Kwolek wyruszyli za ocean. W starych dokumentach nazwy własne (nazwiska, imiona, nazwy miejscowości) mogły zostać zapisane w postaci gwarowej, często jedynej używanej na danym terenie czy w danym środowisku. Powszechne nazwisko urzędowe, w ustabilizowanej postaci, obowiązkowe jest późnym wynalazkiem biurokratycznym. Na ziemiach polskich wprowadzono je dopiero w I połowie XIX wieku (Kaleta 1997: 41). Wtedy też używane wcześniej zwyczajowo przezwiska, przydomki, nazwiska takie jak Kwolek i inne wcześniej wymienione stały się nazwiskami urzędowymi, weszły w obieg prawny i stały się dziedziczne.

Geografia występowania nazwiska Kwolek w dzisiejszej Polsce wyraźnie potwierdza jego regionalny rodowód. Jak widzimy w tabeli 1 , pomimo kolejnych migracji, większość nosicieli tego nazwiska nadal mieszka na południu naszego kraju, najwięcej na Podkarpaciu. Stąd właśnie, z Woli Komborskiej koło Krosna wyemigrował na początku XX wieku do USA Jan Kwolek, po którym Stephanie odziedziczyła nazwisko. Obecność cech gwarowych jest więc w nim zupełnie naturalna. Językoznawcy wiedzą, że Kwolek i Chwatek to dwie różne postacie tego samego nazwiska. Pierwsza gwarowa, druga literacka. Mają tę samą genezę. Ktoś, kto dostrzegł, że rodzina Kwolków mogła wcześniej nosić nazwisko Chwałek, był najprawdopodobniej natywnym użytkownikiem języka polskiego i miał dobrą intuicję językową. Tak mogło być, tzn. urzędowe nazwisko Chwałek mogło - przynajmniej teoretycznie - funkcjonować $\mathrm{w}$ wersji nieoficjalnej, tj. Kwolek, nawet $\mathrm{w}$ tej samej rodzinie albo w różnych jej gałęziach. Dokumenty - przynajmniej te znane i zachowane - tego jednak nie potwierdzają. Rodzina słynnej chemiczki od momentu utrwalenia się jej nazwiska w obiegu społecznym nosi je w postaci gwarowej. 
TABELA 1. Liczba nosicieli nazwiska Kwolek według powiatów ${ }^{12}$

\begin{tabular}{|l|l|c|c|}
\hline Powiat/miasto & Województwo & Razem & $\%$ \\
\hline brzozowski & podkarpackie & $\mathbf{2 8 9}$ & 13,1 \\
\hline krośnieński & podkarpackie & $\mathbf{2 7 5}$ & 12,4 \\
\hline sanocki & podkarpackie & $\mathbf{2 1 1}$ & 9,5 \\
\hline łańcucki & podkarpackie & $\mathbf{1 4 1}$ & 6,4 \\
\hline m. Wrocław & dolnośląskie & $\mathbf{9 4}$ & 4,3 \\
\hline m. Krosno & podkarpackie & $\mathbf{6 5}$ & 2,9 \\
\hline strzyżowski & podkarpackie & $\mathbf{5 7}$ & 2,6 \\
\hline sztumski & pomorskie & $\mathbf{4 5}$ & 2,0 \\
\hline jarosławski & podkarpackie & $\mathbf{3 7}$ & 1,7 \\
\hline rzeszowski & podkarpackie & $\mathbf{3 6}$ & 1,6 \\
\hline m. Kraków & małopolskie & $\mathbf{3 5}$ & 1,6 \\
\hline przeworski & podkarpackie & $\mathbf{3 4}$ & 1,5 \\
\hline m. Rzeszów & podkarpackie & $\mathbf{3 1}$ & 1,4 \\
\hline bieszczadzki & podkarpackie & $\mathbf{3 0}$ & 1,4 \\
\hline dębicki & podkarpackie & $\mathbf{2 9}$ & 1,3 \\
\hline m. Bydgoszcz & kujawsko-pomorskie & $\mathbf{2 5}$ & 1,1 \\
\hline m. Tarnów & małopolskie & $\mathbf{2 2}$ & 1,0 \\
\hline
\end{tabular}

Wracając do początku tych rozważań, można powiedzieć, że najprawdopodobniej przyczyną rozpowszechnionego przekonania, że ojciec Stephanie Kwolek nosił nazwisko Chwałek, jest albo podejrzenie, że nazwisko Kwolek to postać zamerykanizowana (co już wcześniej odrzuciliśmy), albo przekonanie o większym prestiżu nazwiska w postaci literackiej od nazwiska w postaci gwarowej (Gajda 2010: 147-162). W kulturze polskiej dość silnie bowiem zakorzenione jest przekonanie o niższości kultury wiejskiej, „wieśniackiej”. W taki, jeśli wolno mi tak powiedzieć, zabobon kulturowy wierzą szczególnie ci, którzy sami wywodzą się ze wsi, „słoiki”13, ludzie, którzy cierpią na kompleks wieśniaka i dlatego

12 Podaję tylko powiaty, w których w 2002 r. mieszkało więcej niż 20 nosicieli nazwiska. Dane podług: K. Rymut, Słownik nazwisk używanych w Polsce na początku XXI wieku, Kraków 2003. Tabela jest ekstraktem z bardziej szczegółowej tabeli dostępnej online: http://nlp.actaforte.pl:8080/Nomina/Ndistr?nazwisko=Kwolek (dostęp: 19.04.2019), którą oprac. Zbigniew Bronk, Agencja Informatyczna.

13 Nie potrafię ustalić, od kiedy rzeczownika słoik używa się w znaczeniu 'osoba z prowincji, ze wsi, prostak'. Telewizyjny serial pt. „Słoiki” powstał w 2015 r. W tym samym 
chcą się od swojego środowiska świadomie bądź intuicyjnie odciąć, także poprzez odrzucenie gwary i/lub regionalizmów. Jak pokazują badania, „stereotyp wieśniaka jest bardzo głęboko zakorzeniony w kulturze polskiej. [...] wieśniak to mieszkaniec wsi, który ponadto odznacza się następującymi cechami: brakiem obycia, nieznajomością kultury, posługiwaniem się gwarą, prostactwem, brakiem inteligencji." (Gaze 2015: 187). W tej sytuacji ,[g]wara w coraz większym stopniu staje się znakiem nie tyle regionalnej, co po prostu wiejskiej przynależności społecznej, niesie bowiem bagaż negatywnych konotacji wiejskości, stereotypów i kompleksów tkwiących głęboko w świadomości Polaków" (Sikora 2010: 253). To najprawdopodobniej ktoś o takiej mentalności zauważył, że nazwisko Chwałek jest lepsze, bo nie jest wiejskie, nie jest „wieśniackie” i nie jest gwarowe. Nie musimy podążać jego śladem.

\section{BIBLIOGRAFIA}

Ainsworths S., 2014, Stephanie Kwolek Dies at 90, „Chemical \& Engineering News”, t. $92, \mathrm{nr} 26, \mathrm{~s} .8$.

Bailey M., 1998, American Women in Science: 1950 to the Present: a Biographical Dictionary, Santa Barbara, CA.

Bielatowicz J., 1986, Książeczka. Opowiadania starego kaprala, Warszawa.

Brostow W., 2016, Lobland H.E.H., Materials: Introduction and Applications, Hoboken, New Jersey.

Bystroń J. S., 1936, Nazwiska polskie, Lwów-Warszawa.

Cieślikowa A., 1998, Przezwiska, [w:] Polskie nazwy własne. Encyklopedia, red. E. Rzetelska-Feleszko, Warszawa, s. 119-134.

Dejna K., 1993, Dialekty polskie, Wrocław.

Gajda S., 2010, Prestiż a język, „Nauka” t. 4, s. 147-162.

Gaze M., 2015, Językowy obraz wieśniaka we wspótczesnej polszczyźnie, „Studia Obszarów Wiejskich" t. 40, s. 181-187.

Iwańczak W., 2016, Kobieta, która zatrzymała pociski, „Niedziela”, nr 24, s. 44-45. Iwańczak W., 2016, Kobieta, która zatrzymała pociski. Nowe fakty, „Niedziela”, nr 44, s. 22-23.

Jost I., 1983, Osadnictwo kaszubskie w Ontario, Lublin.

Kaleta Z., 1998, Nazwisko w kulturze polskiej, Warszawa.

Kaleta Z., 1997, The surname as a cultural value and an ethnic heritage. Tracing your Polish root, Warsaw.

roku ukazała się książka Steffena Möllera pt. Viva Warszawa! Książka dla turystów, słoików i gastarbeiterów, Bielsko-Biała 2015. 
Karłowicz J., 1900-1911, Słownik gwar polskich, t. 1-6, Kraków.

Kasprzyk P., 2006, Zmiana imienia $i$ nazwiska w prawie polskim (wstęp do problematyki), „Studia Prawnoustrojowe”, nr 6, s. 45-92.

Kresa M., 2014, Janosik - gwara na szklanym ekranie, „Poradnik Językowy”, z. 10, 22-41.

Kucała M., 2002, Twoja mowa cię zdradza, Kraków.

Łobodzińska R., Tomczak L., 1988, Współczesne przezwiska polskie. Analiza formalna i znaczeniowa, Warszawa.

Loś J., 1925, Gramatyka polska. Cz. 2: Słowotwórstwo, Lwów.

Malec M., 1996, O imionach i nazwiskach w Polsce. Tradycja i współczesność, Kraków.

Malec M., 1982, Staropolskie skrócone nazwy osobowe od imion dwuczłonowych, Wrocław.

Meier D., 2014, Ein goldener Faden, der Leben rettet, „Neue Zurcher Zeitung”, 29 Jun 2014, https//www.pressreader.com/switzerland/neue-zurcher-zeitung-sun day/20140629/281951720908872 (dostęp: 18.04.2019).

Möller S., 2015, Viva Warszawa! Książka dla turystów, słoików i gastarbeiterów, Bielsko-Biała.

Nowak A., 2013, Powrót do Łaskiego, „Arcana”, nr 112-113, s. 30-32.

Pigoń S., 1983, Z Komborni w świat. Wspomnienia młodości, Warszawa.

Pomianowska W., 1963, Klasyfikacja rzeczowników odrzeczownikowych. Studium ze słowotwórstwa i geografii lingwistycznej, Wrocław.

Raszewska-Klimas A., 2002, Funkcja nazw własnych w twórczości Marii Dąbrowskiej, Piotrków Trybunalski.

Rymut K., 1998, Nazwiska, [w:] Polskie nazwy własne. Encyklopedia, red. E. Rzetelska-Feleszko, Warszawa, s. 143-160.

Rymut K., 1991, Nazwiska Polaków, Wrocław.

Rymut K., 2003, Słownik nazwisk używanych w Polsce na początku XXI wieku, Kraków.

Rymut K., 2003, Uproszczenie grupy chw > ch staropolszczyźnie, [w:] K. Rymut, Szkice onomastyczne i historycznojezzykowe, Kraków, s. 293-296.

Sikora K., 2010, Gwara na ustugach mediów, [w:] Symbolae grammaticae in honorem Boguslai Dunaj, red. R. Przybylska, J. Kąś, K. Sikora, Kraków, s. 249-266.

Słownik gwar polskich PAN, 1992, red. J. Reichan, t. 4, z. 1(10), Wrocław-Kraków. Słownik nazwisk współcześnie w Polsce używanych, 1992-2004, red. K. Rymut, t. 1-10, Kraków.

Słownik staropolskich nazw osobowych, 1956-1987, red. i wstęp W. Taszycki, t. 1-7, Wrocław.

Swaby R., 2017, Upór i przekora: 52 Kobiety, które odmieniły naukę i świat, Warszawa. 
Tadeusiewicz R., 2016, Kamizelki i hetmy kuloodporne z kevlaru, czyli co zawdzięczaja żotnierze Stefanii Kwolek vel Chwałek, "Gazeta Krakowska”. https://gazeta krakowska.pl/kamizelki-i-helmy-kuloodporne-z-kevlaru-czyli-co-zawdziecz aja-zolnierze-stefanii-kwolek-vel-chwalek/ar/9897449 (dostęp: 18.04.2019).

Tadeusiewicz R., 2012, O życiu i nauce (zbiór felietonów), SKAMER ACM.

\title{
KWOLEK OR CHWAEEK? \\ ON THE MAIDEN NAME OF A FAMOUS CHEMIST
}

\begin{abstract}
Stefania (in the US: Stephanie Louise) Kwolek is an American chemist of Polish descent. Globally, she is primarily known as a co-inventor of kevlar, a material used to manufacture, among other things, bulletproof vests. Numerous works dedicated to the life and achievements of the famous researcher point to doubts with regard to the spelling of her maiden name. According to certain publications, the name Kwolek is either an Americanised or a distorted Polish name Chwatek. The author of this article shows that both surnames have the same origin - Chwałek is a standard, literary form, and Kwolek is a dialectical form, compliant with the pronunciation in the dialects of south-eastern Poland. The form Kwolek started being used by the society in distant past, still before the official codification of surnames on the Polish territory. That was the name used by Stefania's father at the time he emigrated to America, therefore, there is no reason to refer to him by the name Chwałek, even if the name Kwolek may seem less prestigious.
\end{abstract}

Key words: Stephanie Louise Kwolek, Polish surnames, geography of surnames, surnames of Polish immigrants to the US 